\title{
Microalgal Exposure to Human Antibiotics Triggers Similarities in Growth and Photosynthetic Responses
}

\author{
Adeolu Olabode Aderemi ${ }^{1}$, Joanne Roberts ${ }^{2}$, Colin Hunter ${ }^{1}$, Ole Pahl ${ }^{1}$ \\ ${ }^{1}$ Civil Engineering and Environmental Management, Glasgow Caledonian University, Glasgow, UK \\ ${ }^{2}$ SCEBE, Chemical Science, Glasgow Caledonian University, Glasgow, UK \\ Email: *bodeoludunks@yahoo.com
}

How to cite this paper: Aderemi, A.O., Roberts, J., Hunter, C., and Pahl, O. (2021) Microalgal Exposure to Human Antibiotics Triggers Similarities in Growth and Photosynthetic Responses. Journal of Environmental Protection, 12, 509-525. https://doi.org/10.4236/jep.2021.128032

Received: July 1, 2021

Accepted: August 7, 2021

Published: August 10, 2021

Copyright ( 2021 by author(s) and Scientific Research Publishing Inc. This work is licensed under the Creative Commons Attribution International License (CC BY 4.0).

http://creativecommons.org/licenses/by/4.0/ (c) (i) Open Access

\begin{abstract}
The discharge of pharmaceuticals via wastewater into the environment is a great concern due to the constant threat posed to photosynthetic organisms since they are vital for the sustenance of the aquatic food web. To compare the photosynthetic and growth responses of green algae to human antibiotics, Raphidocelis subcapitata and Chlorella vulgaris were exposed to erythromycin and sulfamethoxazole for $96 \mathrm{~h}$. A much higher sensitivity was shown by Raphidocelis to the antibiotics. Although erythromycin was more acutely toxic to photosynthesis $\left(\mathrm{EC}_{50}, 24.6 \mu \mathrm{g} / \mathrm{L} ; \mathrm{EC}_{10}, 14.6 \mu \mathrm{g} / \mathrm{L}\right)$ than growth $\left(\mathrm{EC}_{50}\right.$, $160 \mu \mathrm{g} / \mathrm{L} ; \mathrm{EC}_{10}, 27 \mu \mathrm{g} / \mathrm{L}$ ) in Raphidocelis, chronic effects in terms of $\mathrm{EC}_{10}$ were alike. Interestingly, sulfamethoxazole exhibited similar toxicity towards growth and photosynthesis with the acute and chronic toxicity parameters for growth $\left(\mathrm{EC}_{50},>2000 \mu \mathrm{g} / \mathrm{L} ; \mathrm{EC}_{10}, 260 \mu \mathrm{g} / \mathrm{L}\right.$ for Raphidocelis, and $\mathrm{EC}_{50}, 47,900 \mu \mathrm{g} / \mathrm{L}$; $\mathrm{EC}_{10}, 19,100 \mu \mathrm{g} / \mathrm{L}$ for Chlorella) in consonance with those of photosynthesis $\left(\mathrm{EC}_{50},>2000 \mu \mathrm{g} / \mathrm{L} ; \mathrm{EC}_{10}, 340 \mu \mathrm{g} / \mathrm{L}\right.$ for Raphidocelis, and $\mathrm{EC}_{50}, 47,500 \mu \mathrm{g} / \mathrm{L}$; $\mathrm{EC}_{10}, 13,400 \mu \mathrm{g} / \mathrm{L}$ for Chlorella). Growth and photosynthesis in Raphidocelis were strongly inhibited in this study at environmentally relevant concentrations of erythromycin. The findings from this study demonstrated that photosynthetic yield was a reliable indicator of sulfamethoxazole and erythromycin effects and thus, may be useful as an alternative approach to growth in assessing chronic toxicity in antibiotics.
\end{abstract}

\section{Keywords}

Pharmaceuticals, Antibiotics, Toxicity, Growth, Photosynthesis, Green Algae

\section{Introduction}

The increasing use of pharmaceuticals and their subsequent discharge into the 
aquatic environment via effluents from wastewater treatment works (WWTWs) remain a source of concern [1] [2] [3] [4] [5]. Between the years 2007 and 2017, there was a $20 \%$ increase in the total number of community dispensed pharmaceutical items in Scotland [6]. The global consumption of pharmaceuticals belonging to the class antibiotics, has grown, with an estimated $65 \%$ increase between the years 2000 and 2015 and a $200 \%$ projected global consumption growth for the year 2030 [7]. Only a percentage of the parent pharmaceutical is utilised by the patient with the remainder excreted associated with urine or faeces. There are about 9000 WWTWs that the UK water industry manages [8] and depending on the pharmaceutical, the removal efficiency varies greatly in the generally aerobic processes employed in these treatment plants [9], thus allowing a percentage of the unaffected parent compound into the environment. If the sewage is not treated, then it is expected that the percentage reaching the environment increases. A 2017 United Nations (UN) world water development report stated that on average, about $30 \%$ of the municipal and industrial wastewater generated in high income countries are not treated or inadequately treated. The percentage increases to $62 \%$ in upper middle-income countries and to $72 \%$ in lower middle-income countries while in low-income countries about $92 \%$ do not undergo treatment of any type [10]. Consequently, human pharmaceutical residues in wastewater represent a global threat to non-target aquatic organisms, even at low concentrations, due to their bioactive nature and continuous infusion into the aquatic environment from WWTWs [11]. A recent study commissioned by Centre of Expertise for Waters identified eight pharmaceuticals including two antibiotics as posing a high ecotoxicological risk in Scotland's inland surface waters [12].

The green algae used in this study belong to a diverse group of aquatic photosynthesizing microscopic organisms called phytoplankton [13]. The aquatic food web is sustained by the energy obtained by phytoplankton through photosynthesis [14]. The microalgae rely on this energy to perform necessary functions including growth. In addition, about $50 \%-85 \%$ of the earth's atmospheric oxygen comes from the photosynthetic activity of phytoplankton [15] [16]. Any significant reduction in their photosynthetic efficiency will not only affect their growth adversely but affect the organisms at the upper trophic levels [17]. It is therefore important to investigate the potential adverse effects of human pharmaceuticals on microalgae to evaluate the risk they pose to the aquatic environment. The freshwater green algal species, Raphidocelis subcapitata, have been frequently employed as model organisms to assess the toxicity of many pharmaceuticals particularly antibiotics [18]-[23]. However, lately there has been an increase in the use of the green algae, Chlorella vulgaris, probably due to its prevalence in freshwater systems [24] [25] [26] [27] [28].

The assessment of chemical toxicity using microalgae usually involves a growth inhibition test using the endpoint of algal biomass as described in several guidelines [29]. The method of using chlorophyll a fluorescence determined by Pulse Amplitude Modulation (PAM) fluorometry, although reliable for assessing her- 
bicide and metal toxicity [30] [31] [32], has not been extensively used to evaluate the toxic effects of pharmaceuticals due to their modes of action [33] [34] [35] [36]. The PAM technique provides information about the photosystem II (PS II) effective quantum yield or photosynthetic fitness of the microalgae [37] [38] [39]. It can be used in a quick bioassay because it provides direct information on the photosynthetic efficiency of the algae in contrast to the standardized growth inhibition test which requires at least $72 \mathrm{~h}$ [40]. Escher et al. [33] in their measurement of photosynthesis inhibition in D. subspicatus using PAM obtained 24 $\mathrm{h} \mathrm{EC}_{50}$ for ibuprofen, diclofenac, and carbamazepine that correlate with previously reported $72 \mathrm{~h} \mathrm{EC}_{50}$ for growth inhibition of the same algal species determined according to the OECD guideline [41]. For the macrolide, tylosin, reported $\mathrm{EC}_{50 \text { growth }}$ was up to 140 times higher than effect concentrations obtained using photosynthetic efficiency as acute endpoint [35]. However, this present study intends to exploit the PAM's use as a chronic marker ( $\geq 72 \mathrm{~h})$ of antibiotic effects in comparison to growth inhibition.

This study examined two individual antibiotics selected from a wide range of pharmaceuticals monitored in hospital wastewaters in the EU funded PILLs Project [42] to which this study was linked. The selection of erythromycin (ERY), and sulfamethoxazole (SUF) was based on hospital contribution, European wide usage, and persistence in the environment [42]. They have been identified as antibiotics of high risk in the aquatic environment of Europe, USA and Worldwide due to their consumption, discharge, persistence, and toxic properties [43] [44] [45] [46] [47]. This study was carried out to investigate individual toxicity of ERY and SUF to green algae, $R$. subcapitata and $C$. vulgaris by assessing and comparing effects on two physiological endpoints namely, growth and photosynthesis following $96 \mathrm{hr}$ of exposure.

\section{Methodology}

\subsection{Strain Cultivation}

Unicultures of $R$. subcapitata (CCAP 278/4) and C. vulgaris (CCAP 211/12) purchased from Culture Collection of Algae and Protozoa (CCAP), cultivated in $500 \mathrm{ml}$ conical flasks containing $200 \mathrm{ml}$ sterile Jaworski's Media (JM), were maintained on a shaker $(100 \mathrm{rpm})$ in a culturing apparatus at $20^{\circ} \mathrm{C} \pm 1{ }^{\circ} \mathrm{C}$ under continuous illumination in the range $30-40 \mu \mathrm{mol} \cdot \mathrm{m}^{-2} \cdot \mathrm{s}^{-1}$ of photosynthetic active radiation (PAR). To keep the cultures in an exponential growth phase, algae were aseptically transferred to fresh media every 3 - 4 days.

\subsection{Chlorophyll a Fluorescence Bioassay}

Test concentrations were prepared from the stock solutions of the pharmaceuticals by diluting with JM and, following preliminary range finding experiments; 12.5 - $200 \mu \mathrm{g} / \mathrm{L}$ of ERY; and 125 - $2000 \mu \mathrm{g} / \mathrm{L}$ of SUF were tested against $R$. subcapitata while $C$. vulgaris was exposed to 1560 - 25,000 $\mu \mathrm{g} / \mathrm{L}$ ERY and 12,500 $100,000 \mu \mathrm{g} / \mathrm{L}$ SUF. The samples without pharmaceuticals were used as the con- 
trol. Tests were performed in sterile $3 \mathrm{~mL}$ glass vials containing $0.5 \mathrm{~mL}$ of algae inoculum and $1 \mathrm{~mL}$ of test substance and for validation of the toxicity tests, ammonium dichromate was tested as the positive control. The tests were carried out in triplicates under axenic conditions and test vials were incubated under the same environmental conditions as the algal stock cultures for $96 \mathrm{~h}$. Test vials position was randomised and changed daily [48]. To determine the stability of the pharmaceuticals in the test systems, samples were taken from the control and test vials at the beginning of the tests (without algae) and at $96 \mathrm{~h}$ and stored at $-20^{\circ} \mathrm{C}$ until chemical analysis. The chlorophyll fluorescence intensity of each treatment and control sample was determined immediately after inoculation and every $24 \mathrm{~h}$ using a highly sensitive dual channel ToxY-PAM chlorophyll fluorometer with a ToxYWin Software (Heinz Walz, Effeltrich, Germany) and an average of six measurements taken for each replicate. In the ToxY-PAM blue light is used for excitation and fluorescence is assessed at a wavelength above $650 \mathrm{~nm}$. The $\left(F_{s}\right)$ fluorescence level corresponds to the fluorescence measured shortly before the application of a saturation pulse. The measured fluorescence parameters [Fm (maximum fluorescence and Fs (minimum or steady state fluorescence)] allowed the calculation of the effective quantum yield (Y) of the linear electron transport or the efficiency of PS II photochemistry $\left(\Phi_{\text {PSII }}\right)$ which indicates the capacity of the light adapted cells to convert absorbed light energy to chemical energy. This is used as a proxy for the fitness or efficiency of photosynthetic organisms [37].

$$
\Phi_{\mathrm{PSII}} \text { or } Y=\left(F_{m}-F_{s}\right) / F_{m}
$$

\subsection{Algae Growth Inhibition Test}

Test microalgae were exposed to the individual test pharmaceuticals diluted in JM after range finding experiments. For Raphidocelis, the pharmaceutical concentrations were 1250 - $2000 \mu \mathrm{g} / \mathrm{L}$ SUF, and 12.5 - $200 \mu \mathrm{g} / \mathrm{L}$ ERY. C. vulgaris was exposed to 12,500 - 100,000 $\mu \mathrm{g} / \mathrm{L}$ SUF and 6250 - 100,000 $\mu \mathrm{g} / \mathrm{L}$ ERY. The bioassays were carried out in accordance with OECD Test Guideline 201 [49] and 50 $\mathrm{mL}$ conical flasks (Fisherbrand) containing $20 \mathrm{~mL}$ of test solution were used as test vessels. In each flask, a specified volume of algal culture in the range 1.5 to 2 $\mathrm{mL}$, in exponential growth phase (3 - 4 day old) was diluted with a known volume of JM (18 to $18.5 \mathrm{~mL}$ ), with or without pharmaceuticals, to obtain an initial cell biomass in the range 300,000 to 700,000 cells/mL for $R$. subcapitata and $1 \times$ $10^{6}$ to $1.5 \times 10^{6}$ cells $/ \mathrm{mL}$ for $C$. vulgaris. Each concentration of the pharmaceutical and the control was tested in triplicates.

The tests were run for $96 \mathrm{~h}$ under the same standard conditions used for the inoculum culture. The positions of test flasks were randomized and changed every $24 \mathrm{~h}$ for uniform light distribution. Cell densities were determined every $24 \mathrm{~h}$ by loading a haemocytometer with $10 \mu \mathrm{L}$ of each sample and counting under the $40 \times$ objective, employing a Leica DM500 microscope in the bright field configuration. There were no significant changes in the $\mathrm{pH}$ of the control and 
treatments before and after the assays. Stability of the pharmaceuticals in the test systems was determined by taking samples from the control and treatment vessels at 0,48 and $96 \mathrm{~h}$ and stored at $-20^{\circ} \mathrm{C}$ until further analysis.

\subsection{Pharmaceutical Analysis}

Samples were filtered through $0.2 \mu \mathrm{m}$ cellulose filter prior to chemical analysis. Liquid chromatography mass spectrometry (LC-MS/MS) was used to determine the actual concentrations of the pharmaceuticals. The LC system was an Agilent 1100 Series LC equipped with a Phenomenex, $5 \mathrm{~cm}$ Kinetex SD C18 $(50 \mathrm{~mm} \times$ $2.10 \mathrm{~mm}$ ) column. The Bruker 3000 Esquire plus Ion Trap mass spectrometer with electrospray ionization (ESI) source was operated in positive ion mode. For each sample, $10 \mu \mathrm{l}$ was injected using an auto-sampler. Mobile phase was 10 mmol ammonium formate (adjusted to $\mathrm{pH}=3.5$ by formic acid), and acetonitrile. The flow rate was $1.0 \mathrm{ml} / \mathrm{min}$. All detections were performed by mass spectrometry (MS), in which the $\mathrm{m} / \mathrm{z}$ transition for the drugs was as follows: $254 \rightarrow$ 155.9 for SUF, and $734.47 \rightarrow 158.1$ for ERY.

\subsection{Statistical Analysis}

Inhibitions of growth and photosynthesis were expressed as percentages of the control. The effective concentration (EC) of each pharmaceutical that inhibited $10 \%\left(\mathrm{EC}_{10}\right), 20 \%\left(\mathrm{EC}_{20}\right)$ and $50 \%\left(\mathrm{EC}_{50}\right)$ of the algal growth and photosynthesis in respect to the control and their 95\% confidence intervals (CI) were determined by linear interpolation and Probit analysis using SPSS statistics package (v21, SPSS Company) [21]. The LOEC (Lowest Observed Effect Concentration) and NOEC (No Observed Effect Concentration) values for each test pharmaceuticals were determined after normality test (Shapiro-Wilk). To determine these chronic toxicity indices, a one-way analysis of variance (ANOVA) followed by Tukey and Games-Howell post hoc test were performed using SPSS statistics v26 programme. A $p$ value $<0.05$ was considered statistically significant.

Although, the assays used in this study were short-term assays and are most often considered as acute toxicity assays [50] [51], they are in principle multigenerational assays, and can also be considered as chronic toxicity tests [52] [53]. According to the EU Technical Guidance Document [54], 72-h (or longer) exposure studies with alga $\mathrm{EC}_{50}$ values can be considered as equivalent to shortterm exposure parameters, and the NOEC values can be considered as long-term exposure parameters. In addition, the regression-based approach $\left(\mathrm{EC}_{10}\right)$ has been suggested as a better indicator of low toxic effect levels [55] [56].

\section{Results}

\subsection{Effects on Algal Photosynthesis}

Table 1 shows the effects of the test antibiotics on the photosynthesis of $C$. vulgaris and $R$. subcapitata within 24 to $96 \mathrm{~h}$ of exposure. Hormetic effects were induced in $C$. vulgaris at $24 \mathrm{~h}$ of exposure to SUF. However, the antibiotic 
Table 1. Photosynthetic inhibition (\%) in microalgae following a 96-h exposure to antibiotics.

\begin{tabular}{|c|c|c|c|c|}
\hline$\mu \mathrm{g} / \mathrm{L}$ & $24 \mathrm{~h}$ & $48 \mathrm{~h}$ & $72 \mathrm{~h}$ & $96 \mathrm{~h}$ \\
\hline \multicolumn{5}{|l|}{ Chlorella } \\
\hline \multicolumn{5}{|l|}{ SUF } \\
\hline 12,500 & $-10.14 \pm 2.6$ & $0.55+1.1$ & $12.59+1.4$ & $9.82 \pm 1.8$ \\
\hline 25,000 & $-16.1^{a} \pm 0.3$ & $14.54+3.1$ & $22.10^{\mathrm{a}}+0.5$ & $19.89^{b}+6.0$ \\
\hline 50,000 & $-23.4^{\mathrm{b}} \pm 3.2$ & $27.5^{\mathrm{b}}+6.4$ & $64.46^{c}+3.1$ & $53.33^{c}+1.3$ \\
\hline 100,000 & $-26.4^{c} \pm 2.2$ & $41.6^{c}+10.1$ & $79.31^{c}+7.4$ & $96.98^{c}+0.4$ \\
\hline \multicolumn{5}{|l|}{ ERY } \\
\hline 1560 & $-1.91 \pm 1.3$ & $-8.71^{\mathrm{a}} \pm 0.7$ & $-7.8 \pm 1.5$ & $-4.86 \pm 1.1$ \\
\hline 3120 & $-1.74 \pm 1.7$ & $-7.49^{\mathrm{a}} \pm 2.0$ & $-7.0 \pm 0.8$ & $-2.23 \pm 2.5$ \\
\hline 6250 & $-1.52 \pm 0.6$ & $-6.38 \pm 1.2$ & $-3.21 \pm 1.6$ & $0.25 \pm 1.0$ \\
\hline 12,500 & $-0.53 \pm 0.8$ & $-1.99 \pm 2.2$ & $-0.34 \pm 3.5$ & $3.64 \pm 0.5$ \\
\hline 25,000 & $3.96 \pm 1.5$ & $7.22^{\mathrm{a}} \pm 1.3$ & $9.90^{\mathrm{a}} \pm 2.6$ & $13.03^{c} \pm 3.1$ \\
\hline \multicolumn{5}{|c|}{ Raphidocelis } \\
\hline \multicolumn{5}{|c|}{ SUF } \\
\hline 125 & $-0.94 \pm 1.5$ & $-5.20^{\mathrm{b}}+1.5$ & $0.17+1.1$ & $4.25 \pm 2.9$ \\
\hline 250 & $-0.06 \pm 0.9$ & $-1.26+0.9$ & $0.92+1.3$ & $5.65+2.9$ \\
\hline 500 & $0.81 \pm 1.0$ & $1.14+0.8$ & $14.68^{c}+1.2$ & $17.71^{c}+2.3$ \\
\hline 1000 & $3.73 \pm 1.9$ & $8.51^{c}+0.7$ & $19.73^{c}+1.0$ & $28.21^{c}+0.8$ \\
\hline 2000 & $3.33 \pm 0.5$ & $9.75^{c} \pm 1.1$ & $25.66^{c} \pm 1.5$ & $37.62^{c} \pm 1.8$ \\
\hline \multicolumn{5}{|l|}{ ERY } \\
\hline 12.5 & $-2.40 \pm 1.8$ & $-0.81 \pm 1.2$ & $0.01 \pm 0.9$ & $1.23 \pm 4.4$ \\
\hline 25 & $-2.51 \pm 2.4$ & $3.13 \pm 1.1$ & $39.58^{c} \pm 1.7$ & $51.57^{\mathrm{b}} \pm 2.3$ \\
\hline 50 & $0.33 \pm 3.2$ & $8.63^{\mathrm{a}} \pm 2.2$ & $55.42^{c} \pm 1.2$ & $97.37^{c} \pm 0.3$ \\
\hline 100 & $5.92 \pm 2.3$ & $21.64^{c} \pm 1.6$ & $65.76^{c} \pm 0.9$ & $98.92^{c} \pm 0.1$ \\
\hline 200 & $24.20^{c} \pm 3.8$ & $33.30^{c} \pm 1.6$ & $73.74^{c} \pm 1.7$ & $99.56^{c} \pm 0.1$ \\
\hline
\end{tabular}

SUF, ERY: Sulfamethoxazole, Erythromycin; Values are Mean $\pm \mathrm{SE}, \mathrm{n}=3{ }^{\mathrm{a}} \mathrm{p}<0.05,{ }^{\mathrm{b}} \mathrm{p}<0.01,{ }^{\mathrm{c}} \mathrm{p}<0.001$.

caused a significant inhibition in $\Phi_{\text {PSII }}$ of Chlorella at 50,000 and 25,000 $\mu \mathrm{g} / \mathrm{L}$ at 48 and $72-96 \mathrm{~h}$ respectively (Table 1). Inhibition increased from $14.5 \%$ at $48 \mathrm{~h}$ to $19.8 \%$ at $96 \mathrm{~h}$ in the $25,000 \mu \mathrm{g} / \mathrm{L}$ treatment. The decrease of photosynthesis in Raphidocelis at $2000 \mu \mathrm{g} / \mathrm{L}$ after $24 \mathrm{~h}$ was not significant $(\mathrm{p}<0.05)$ and SUF became toxic with time with LOECs of 1000 and $500 \mu \mathrm{g} / \mathrm{L}$ noted at 48 and $72-96 \mathrm{~h}$ respectively (Table 1 ). For the $500 \mu \mathrm{g} / \mathrm{L}$ treatment, a rise in photosynthetic inhibition from $0.81 \%$ at $24 \mathrm{~h}$ to $17.7 \%$ at $96 \mathrm{~h}$ was observed.

In $C$. vulgaris exposure, ERY enhanced $\Phi_{\text {PSII }}$ with significant stimulation noted shortly by $48 \mathrm{~h}$ (up to $8.7 \%$ ) at $1560 \mu \mathrm{g} / \mathrm{L}$ (Table 1 ). Significant inhibition ( $\mathrm{p}<$ $0.05 ; 7.2 \%$ to $13 \%$ ) of $\Phi_{\mathrm{PSII}}$ in Chlorella was seen only at the highest tested concentration $(25,000 \mu \mathrm{g} / \mathrm{L})$ of ERY from $48-96 \mathrm{~h}$. ERY was toxic at $24 \mathrm{~h}$ with LOEC of $200 \mu \mathrm{g} / \mathrm{L}$ and inhibiting $\Phi_{\text {PSII }}$ by $24 \%$. The toxic effects of ERY on $\Phi_{\text {PSII }}$ in Raphidocelis increased with time and concentration-dependent significant ef- 
fects were induced by 48 and 72 - $96 \mathrm{~h}$ (Table 1). The inhibition of $\Phi_{\text {PSII }}$ at 25 $\mu \mathrm{g} / \mathrm{L}$ increased from $3.1 \%$ at $48 \mathrm{~h}$ to $51.5 \%$ at $96 \mathrm{~h}$.

\subsection{Effects on Algal Growth}

The effects of the test antibiotics on growth in C. vulgaris and $R$. subcapitata within 24 to $96 \mathrm{~h}$ of exposure are shown in Table 2. SUF had no notable effects on growth in $R$. subcapitata until $48 \mathrm{~h}$ with a LOEC of $1000 \mu \mathrm{g} / \mathrm{L}$ (Table 2). Its toxicity increased afterwards with $72-96 \mathrm{~h} \mathrm{LOEC}$ of $500 \mu \mathrm{g} / \mathrm{L}$. A similar pattern was exhibited in Chlorella with lower concentrations $(12,500-25,000 \mu \mathrm{g} / \mathrm{L})$ of SUF stimulating growth within $24 \mathrm{~h}$ and toxic effects increased with time with LOECs of 100,000, 50,000, and 25,000 and 12,500 $\mu \mathrm{g} / \mathrm{L}$ at 24, 48, 72, and $96 \mathrm{~h}$ respectively.

Table 2. Growth inhibition (\%) in microalgae following a 96-h exposure to antibiotics.

\begin{tabular}{|c|c|c|c|c|}
\hline$\mu \mathrm{g} / \mathrm{L}$ & $24 \mathrm{~h}$ & $48 \mathrm{~h}$ & $72 \mathrm{~h}$ & $96 \mathrm{~h}$ \\
\hline \multicolumn{5}{|c|}{ Chlorella } \\
\hline \multicolumn{5}{|l|}{ SUF } \\
\hline 12,500 & $-5.53^{\mathrm{b}} \pm 0.8$ & $-0.40+0.4$ & $0.97+0.6$ & $5.73^{\mathrm{a}} \pm 0.9$ \\
\hline 25,000 & $-3.85^{\mathrm{a}} \pm 1.0$ & $2.48+1.0$ & $6.35^{b}+0.9$ & $8.90^{b}+1.3$ \\
\hline 50,000 & $-2.03 \pm 0.4$ & $27.73^{c}+0.7$ & $48.04^{c}+0.6$ & $61.30^{c}+0.3$ \\
\hline 100,000 & $30.92^{c} \pm 0.9$ & $62.61^{c}+1.0$ & $72.29^{c}+0.5$ & $82.50^{c}+0.4$ \\
\hline \multicolumn{5}{|l|}{ ERY } \\
\hline 6250 & $-32.8^{\mathrm{b}} \pm 1.9$ & $-19.45^{\mathrm{b}} \pm 4.4$ & $-15.13^{\mathrm{b}} \pm 1.4$ & $-9.25^{\mathrm{a}} \pm 1.8$ \\
\hline 12,500 & $-23.2^{\mathrm{a}} \pm 4.8$ & $-11.00^{\mathrm{a}} \pm 2.1$ & $-4.4 \pm 0.9$ & $-1.10 \pm 0.9$ \\
\hline 25,000 & $-1.31 \pm 2.1$ & $2.15 \pm 0.45$ & $6.68 \pm 0.7$ & $12.10^{\mathrm{a}} \pm 1.9$ \\
\hline 50,000 & $-0.40 \pm 1.2$ & $16.80^{\mathrm{b}} \pm 1.0$ & $25.60^{c} \pm 2.9$ & $38.35^{c} \pm 2.4$ \\
\hline 100,000 & $19.90^{\mathrm{a}} \pm 4.8$ & $33.35^{\mathrm{c}} \pm 1.1$ & $42.55^{c} \pm 1.4$ & $53.00^{c} \pm 2.0$ \\
\hline \multicolumn{5}{|c|}{ Raphidocelis } \\
\hline \multicolumn{5}{|l|}{ SUF } \\
\hline 125 & $-0.56 \pm 0.2$ & $-5.40+0.8$ & $0.03+1.4$ & $3.48 \pm 1.6$ \\
\hline 250 & $-4.4 \pm 0.3$ & $-1.53+2.4$ & $0.30+2.3$ & $8.63+2.7$ \\
\hline 500 & $0.98 \pm 0.7$ & $0.25+2.7$ & $15.00^{c}+1.5$ & $17.26^{\mathrm{c}}+1.2$ \\
\hline 1000 & $1.49 \pm 0.9$ & $9.70^{\mathrm{a}}+1.1$ & $19.96^{c}+1.8$ & $32.56^{c}+2.9$ \\
\hline 2000 & $1.86 \pm 1.1$ & $10.73^{\mathrm{a}} \pm 1.1$ & $28.26^{c} \pm 0.9$ & $39.36^{\mathrm{c}} \pm 2.8$ \\
\hline \multicolumn{5}{|l|}{ ERY } \\
\hline 12.5 & $-20.8^{\mathrm{c}} \pm 2.2$ & $-9.00 \pm 2.4$ & $-2.16 \pm 0.9$ & $1.75 \pm 0.5$ \\
\hline 25 & $-10.34 \pm 3.6$ & $-1.15 \pm 2.7$ & $2.75 \pm 0.8$ & $13.63^{\mathrm{c}} \pm 1.7$ \\
\hline 50 & $-0.56 \pm 1.1$ & $2.86 \pm 2.7$ & $11.02^{\mathrm{a}} \pm 2.4$ & $20.28^{c} \pm 0.8$ \\
\hline 100 & $1.67 \pm 1.0$ & $14.85^{\mathrm{a}} \pm 2.7$ & $28.02^{c} \pm 1.2$ & $35.24^{\mathrm{c}} \pm 0.6$ \\
\hline 200 & $10.68 \pm 1.5$ & $26.71^{c} \pm 2.9$ & $47.63^{c} \pm 1.6$ & $57.13^{c} \pm 2.0$ \\
\hline
\end{tabular}

SUF, ERY: Sulfamethoxazole, Erythromycin; Values are Mean $\pm \mathrm{SE}, \mathrm{n}=3$; ${ }^{\mathrm{a}} \mathrm{p}<0.05,{ }^{\mathrm{b}} \mathrm{p}<0.01,{ }^{\mathrm{c}} \mathrm{p}<0.001$. 
For C. vulgaris, low ERY concentrations (6250 \& 12,500 $\mu \mathrm{g} / \mathrm{L})$ exerted stimulatory effects up to $48 \mathrm{~h}$. ERY toxicity towards growth yield in Chlorella increased with time and LOECs of 100,000, 50,000, and 25,000 $\mu \mathrm{g} / \mathrm{L}$ were observed within 24, 48 - 72, and 96 h respectively. By 24 h of exposure, ERY had no significant inhibitory effects on growth in Raphidocelis but rather caused a significant stimulation at $12.5 \mu \mathrm{g} / \mathrm{L}$. It became toxic overtime with LOECs of 100,50 and $25 \mu \mathrm{g} / \mathrm{L}$ observed at 48, 72, and $96 \mathrm{~h}$ (Table 2).

\subsection{Toxicity Ranking}

The $96 \mathrm{~h} \mathrm{EC}_{10}, \mathrm{EC}_{20}, \mathrm{EC}_{50}$ as well as LOEC and NOEC values obtained for the various pharmaceuticals tested against photosynthetic efficiency and growth in the algal species are shown in Table 3. In $C$. vulgaris, after $96 \mathrm{~h}$ exposure period, the acute toxicity ranking of the pharmaceuticals towards $\Phi_{\mathrm{PSII}}$ based on $\mathrm{EC}_{50}$ is SUF $\left(\mathrm{EC}_{50}, 47,500 \mu \mathrm{g} / \mathrm{L}\right)>\mathrm{ERY}\left(\mathrm{EC}_{50},>25,000 \mu \mathrm{g} / \mathrm{L}\right)$ and the chronic toxicity ranking based on NOEC or $\mathrm{EC}_{10}$ is SUF (NOEC, 12,500 $\mu \mathrm{g} / \mathrm{L} ; \mathrm{EC}_{10}, 13,400$ $\mu \mathrm{g} / \mathrm{L})>$ ERY $\left(\mathrm{NOEC}, 12,500 \mu \mathrm{g} / \mathrm{L} ; \mathrm{EC}_{10}, 20,900 \mu \mathrm{g} / \mathrm{L}\right)$. For $R$. subcapitata, acute toxicity to photosynthesis is ranked in the following order: ERY $\left(\mathrm{EC}_{50}, 24.6\right.$ $\mu \mathrm{g} / \mathrm{L})>\operatorname{SUF}\left(\mathrm{EC}_{50},>2000 \mu \mathrm{g} / \mathrm{L}\right)$; and chronic toxicity in the order, ERY (NOEC, $\left.12.5 \mu \mathrm{g} / \mathrm{L} ; \mathrm{EC}_{10}, 14.6 \mu \mathrm{g} / \mathrm{L}\right)>\mathrm{SUF}\left(\mathrm{NOEC}, 250 \mu \mathrm{g} / \mathrm{L} ; \mathrm{EC}_{10}, 340 \mu \mathrm{g} / \mathrm{L}\right)$.

The most acutely and chronically toxic compound to the growth of $R$. subcapitata was ERY $\left(\mathrm{EC}_{50}, 160 \mu \mathrm{g} / \mathrm{L}\right.$; NOEC, $\left.12.5 \mu \mathrm{g} / \mathrm{L}\right)$ followed by SUF $\left(\mathrm{EC}_{50},>\right.$ $2000 \mu \mathrm{g} / \mathrm{L}$; NOEC, $250 \mu \mathrm{g} / \mathrm{L})$. For $C$. vulgaris exposure, in terms of acute and chronic toxicity, SUF was the most toxic compound $\left(\mathrm{EC}_{50}, 47,900 \mu \mathrm{g} / \mathrm{L}\right.$; NOEC, $<12,500 \mu \mathrm{g} / \mathrm{L})$ followed by ERY $\left(\mathrm{EC}_{50}, 84,100 \mu \mathrm{g} / \mathrm{L}\right.$; NOEC, 12,500 $\left.\mu \mathrm{g} / \mathrm{L}\right)$. Since effects on the yield of photosynthesis was investigated in this study, the inhibitory

Table 3. Toxicity indices $(\mu \mathrm{g} / \mathrm{L})$ for test pharmaceuticals after $96 \mathrm{~h}$.

\begin{tabular}{lccc}
\hline \multicolumn{1}{c}{ Drug/Endpoint } & $\mathrm{EC}_{10} / \mathrm{EC}_{20}$ & $\mathrm{EC}_{50}$ & \\
\hline $\begin{array}{l}\text { Raphidocelis } \\
\text { SUF }\end{array}$ & & & \\
Growth & $260 / 590$ & $>2000$ & $500 / 250$ \\
Photosynthesis & $340 / 610$ & $>2000$ & $500 / 250$ \\
ERY & & & \\
Growth & $14.6 / 17$ & 160 & $25 / 12.5$ \\
Photosynthesis & & 24.6 & $25 / 12.5$ \\
Chlorella & & & \\
SUF & $19,100 / 26,200$ & 47,900 & $12,500 /<12,500$ \\
Growth & $13,400 / 25,100$ & 47,500 & $25,000 / 12,500$ \\
Photosynthesis & $19,200 / 31,900$ & 84,100 & $25,000 / 12,500$ \\
ERY & $20,960 />25,000$ & $>25,000$ & \\
Growth & & & \\
Photosynthesis & & & \\
\hline
\end{tabular}

SUF: Sulfamethoxazole, ERY: Erythromycin. 
concentration for growth yield was selected above growth rate as the endpoint of comparison to photosynthetic yield. The Commission Directive 67/548/EEC classifies substances according to their $\mathrm{EC}_{50}$ values for aquatic organisms as follows: very toxic $\left(\mathrm{EC}_{50}, \leq 1000 \mu \mathrm{g} / \mathrm{L}\right)$, toxic $\left(\mathrm{EC}_{50},>1000\right.$ to $\left.\leq 10,000 \mu \mathrm{g} / \mathrm{L}\right)$, and harmful $\left(\mathrm{EC}_{50},>10,000\right.$ to $\leq 100,000 \mu \mathrm{g} / \mathrm{L}$ ) (European Commission, 2001). Substances with an $\mathrm{EC}_{50}>100,000 \mu \mathrm{g} / \mathrm{L}$ would not be classified. This classification however depends on the test species and the endpoint used. For both phenotypic endpoints, in this present study with $R$. subcapitata, ERY was classified as very toxic, and SUF classified as toxic, whereas, with $C$. vulgaris, both antibiotics were classified as harmful.

\subsection{Analysis of Exposure Concentrations}

In both chlorophyll fluorescence and growth inhibition assays, almost all the pharmaceutical concentrations were within $80 \%-120 \%$ of the nominal concentrations [49]. Concentrations did not fall under $83 \%$ of the nominal values. Since no significant differences were found between the nominal and measured exposure concentrations of the test pharmaceuticals, the nominal concentrations were used for data analyses throughout this study.

\section{Discussion}

The higher sensitivity shown in both the photosynthetic and growth inhibition assays by $R$. subcapitata to the antibiotics, compared to $C$. vulgaris, agrees with findings from previous work evaluating the toxicity of antimicrobial agents on these species [24]. Kasai and Hatakeyama [57] and Kasai et al. [58] also reported the same tendency in the sensitivity of these algae to several herbicides, ascribing the higher resistance in $C$. vulgaris partly to its thicker cell wall and superior enzyme activities. The growth and photosynthetic stimulatory responses of the test algae to low doses of pharmaceutical stress observed in this study, a phenomenon known as hormesis has been widely reported in plants and algae [59] [60].

The toxic effects of SUF on growth in this study agreed with previous report by Nie et al. [61]. In addition, the LOEC $(500 \mu \mathrm{g} / \mathrm{L})$ obtained for Raphidocelis using the photosynthetic endpoint in this study correlated with the value reported by Liu et al. [62]. The toxic effects of SUF on Chlorella have been scarcely investigated [25] [63], and a much higher $\mathrm{EC}_{50}(18 \times)$ was obtained for SUF in this study. The discrepancy in results may be attributed to the differences in assay techniques, culturing conditions and algal media used.

SUF exhibited similar toxicity towards growth and photosynthesis in Raphidocelis and Chlorella in this study. It is quite intriguing that despite the vast differences in the techniques used, the toxicity parameters $\left(\mathrm{EC}_{10}, \mathrm{EC}_{20}\right.$ and $\left.\mathrm{EC}_{50}\right)$ for growth yield are in consonance with those of the photosynthetic yield for each of the microalgae following SUF exposure (Table 3). This suggests the possibility of a similar mechanism of toxicity being employed by the antibiotic against both endpoints. Sulfonamides are known to inhibit tetrahydrofolic acid synthesis in bacteria and some eukaryotes via the inhibition of dihydropterinic acid synthe- 
tase, and the growth inhibitory effect of SUF on green algae is attributed to this mechanism of action [24]. Interestingly, several studies in the past have argued that pteridines including tetrahydrofolate may be involved in the stimulation of photophosphorylation in autotrophs [64] [65] [66]. Consequently, the possible participation of tetrahydrofolic acid in the photosynthetic process is supported by the strong link and the similarities in the toxic responses obtained for the endpoints of algal growth and photosynthesis in this study. This indicates that the photosynthetic yield may be used as a reliable alternative for growth yield in measuring the toxicity of sulfonamides.

The NOEC values $(<1000 \mu \mathrm{g} / \mathrm{L})$ obtained for SUF using both endpoints, particularly against Raphidocelis suggest that the sulfonamide can cause a long-term adverse effect in the environment [67]. Although, the toxic levels obtained for SUF in this study are above present environmentally realistic levels, its coexistence with other antibiotics or contaminants that are highly toxic to green algae could cause synergistic effects and pose a major risk to algal growth and photosynthesis in the aquatic environment. Further studies investigating its mixture toxicity is therefore recommended.

ERY presented the highest threat (both short term and long term) to the growth of $R$. subcapitata with $96 \mathrm{~h} \mathrm{EC} 50$ of $167 \mu \mathrm{g} / \mathrm{L}$ and LOECs of $50 \mu \mathrm{g} / \mathrm{L}$ respectively. Macrolides inhibit protein synthesis by binding to the $23 \mathrm{~S}$ rRNA molecule in the 50S subunit of the bacterial ribosome. ERY's high toxicity to growth in $R$. subcapitata has been widely reported with $\mathrm{EC}_{50}$ values ranging between 20 $350 \mu \mathrm{g} / \mathrm{L}$ [24] [53] [18] [61] [47]. An $\mathrm{EC}_{50}$ of 33,800 $\mu \mathrm{g} / \mathrm{L}$ was reported for $C$. vulgaris [24] following ERY exposure which is lower than the value reported in this study.

ERY was more acutely toxic to photosynthesis than growth in Raphidocelis with a lower $\mathrm{EC}_{50}$ value of $24.6 \mu \mathrm{g} / \mathrm{L}$. However, ERY elicited similar chronic and low toxic responses from growth yield and photosynthetic yield in both algal species (Table 3). This correlation further corroborates the argument of Liu et al. [62] that the toxic effects of certain antibiotics to green algae could be associated with the retardation of metabolism in the chloroplast facilitating a disturbance in the function of photosynthetic apparatus and eventually inhibiting cell growth. Although, the green alga is a non-target organism for antimicrobials, and unlike herbicides, none of the test antibiotics are specifically designed to affect the photosynthetic apparatus, the relatively high toxicity exerted by ERY towards photosynthetic activity in $R$. subcapitata in this study could partly be as a result of the cyanobacterial nature of the replicating, transcriptional and translational system of chloroplasts which make these plastids susceptible as potential antibiotic targets [18] [68].

ERY has been detected up to a concentration of $90 \mu \mathrm{g} / \mathrm{L}$ (higher than the LOEC or $\mathrm{EC}_{20}$ for growth in this study) in surface water [43] and was also detected in a river body in Scotland up to $24.2 \mu \mathrm{g} / \mathrm{L}$ [69] which is close to $\mathrm{EC}_{10 \text { growth }}$ and equivalent to $\mathrm{EC}_{50 \text { photosynthesis }}$ in this present study. This shows that ERY will adversely affect growth and photosynthesis of $R$. subcapitata in the ecosystem at 
some of the concentrations at which they occur in the environment. The macrolide drugs were placed on the "watch list" of chemicals monitored under the Water Framework Directive (WFD) because of their high ecotoxicity as well as the risk they posed to human health through the development or selection of antibiotic resistant bacteria in the environment [70]. The results obtained in this study further indicate that the release of ERY into the aquatic environment after therapeutic use poses a significant long-term ecotoxicological risk to the microalgal community. In this study, photosynthesis was a more sensitive parameter for the macrolide, ERY probably due to its mode of action and it would likely be a reliable endpoint for antibiotics designed to target bacterial protein synthesis and/or DNA replication. Majority of the toxicity studies using algae are 3 - 4 days exposures [13] and chronic studies ( $\geq 7$ days exposure) investigating the molecular pathways or mechanisms of toxic effects of antibiotics on microalgae should be carried out as this is not fully understood.

\section{Conclusion}

ERY was highly toxic to $R$. subcapitata, strongly inhibiting growth and photosynthesis in this study at environmentally relevant concentrations. Consequently, their release into the environment via WWTPs after normal therapeutic continues to pose a substantial risk to the phytoplankton community. The findings from this study showed that photosynthetic yield was a reliable indicator of SUF and ERY effects and thus, may be used as an alternative approach to growth in assessing toxicity. Since photosynthesis was found to be more sensitive to the ERY than growth in $R$. subcapitata partly due to the evolutionary conservation of the bacterial genome/translational system and their effect pathways in the chloroplasts of green algae [68], it can be implied that the endpoint will be useful in assessing chronic toxicity in antibiotics that are known to interfere with bacterial protein synthesis or DNA replication. It will be therefore useful to employ the photosynthetic efficiency endpoint as a tool in evaluating the chronic effects of a wide range of antibiotics and their mixtures, based on their modes of action, in a variety of freshwater green algae at different levels of biological continuum.

\section{Acknowledgements}

This work was partly funded by the EU Transnational Territorial Cooperation programme INTERREG IVB NWE projects (PILLS project 008B \& "noPILLS in our waters"); this support is greatly acknowledged.

\section{Conflicts of Interest}

The authors declare no conflicts of interest regarding the publication of this paper.

\section{References}

[1] Hughes, S.R., Kay, P. and Brown, L.E. (2013) Global Synthesis and Critical Evalua- 
tion of Pharmaceutical Data Sets Collected from River Systems. Environmental Science and Technology, 47, 661-677. https://doi.org/10.1021/es3030148

[2] Lyons, G. (2014) Pharmaceuticals in the Environment: A Growing Threat to Our Tap Water and Wildlife. CHEM Trust Report. https://www.chemtrust.org.uk

[3] Comber, S., Gardner, M., Sorme, P., Leverett, D. and Ellor, B. (2018) Active Pharmaceutical Ingredients Entering the Aquatic Environment from Wastewater Treatment Works: A Cause for Concern? Science of the Total Environment, 613-614, 538-547. https://doi.org/10.1016/j.scitotenv.2017.09.101

[4] Phonsiri, V., Choi, S., Nguyen, C., Tsai, Y-L., Coss, R. and Kurwadkar, S. (2019) Monitoring Occurrence and Removal of Selected Pharmaceuticals in Two Different Wastewater Treatment Plants. SN Applied Sciences, 1, Article No. 798. https://doi.org/10.1007/s42452-019-0774-Z

[5] Angeles, L.F., Mullen, R.A., Huang, I.J., et al. (2020) Assessing Pharmaceutical Removal and Reduction in Toxicity Provided by Advanced Wastewater Treatment Systems. Environmental Science: Water Research \& Technology, 6, 62-77. https://doi.org/10.1039/C9EW00559E

[6] ISD Scotland (2017) Prescribing and Medicines: Prescription Cost Analysis $2015 / 2016$.

http://www.isdscotland.org/Health-Topics/Prescribing-and-Medicines/Community -Dispensing/Prescription-Cost-Analysis/

[7] Klein, E.Y., Van Boeckel, T.P., Martinez, E.M., Pant, S., Gandra, S., et al. (2018) Global Increase and Geographic Convergence in Antibiotic Consumption between 2000 and 2015. Proceedings of the National Academy of Sciences of the United States of America, 115, E3463-E3470. https://doi.org/10.1073/pnas.1717295115

[8] DEFRA, Defra Department for Environment, Food and Rural Affair (2012) Wastewater Treatment in the United Kingdom-2012 Implementation of the European Union Urban Wastewater Treatment Directive-91/271/EEC. DEFRA, London.

[9] Gardner, M., Jones, V., Comber, S., et al. (2013) Performance of UK Wastewater Treatment Works with Respect to Trace Contaminants. The Science of the Total Environment, 456-457, 359-369. https://doi.org/10.1016/j.scitotenv.2013.03.088

[10] WWAP, World Water Assessment Programme, UN (2017) The United Nations World Water Development Report 2017: Wastewater, the Untapped Resource. UNESCO, Paris.

[11] Henschel, K.P., Wenzel, A., Diedrich, M. and Fliedner, A. (1997) Environmental Hazard Assessment of Pharmaceuticals. Regulatory Toxicology and Pharmacology, 25, 220-225. https://doi.org/10.1006/rtph.1997.1102

[12] Helwig, K., Aderemi, A.O., Donnelly, D., Gibb, S., et al. (2021) Pharmaceuticals in the Water Environment: Baseline Assessment and Recommendations. Technical Report, Centre of Expertise for Waters CREW.

[13] Sharma, L., Siedlewicz, G. and Pazdro, K. (2021) The Toxic Effects of Antibiotics on Freshwater and Marine Photosynthetic Microorganisms: State of the Art. Plants, 10, 591. https://doi.org/10.3390/plants10030591

[14] Calbet, A. and Landry, M.R. (2004) Phytoplankton Growth, Microzooplankton Grazing, and Carbon Cycling in Marine Systems. Limnology and Oceanography, 49, 51-57. https://doi.org/10.4319/10.2004.49.1.0051

[15] Roach, J. (2004) Source of Half Earth's Oxygen Gets Little Credit. https://www.nationalgeographic.com/science/article/source-of-half-earth-s-oxygengets-little-credit\#: :text=All\%20living\%20things $\% 20$ that $\% 20$ make,to $\% 20$ these $\% 20 \mathrm{o}$ nce $\% 2$ Dcelled $\% 20$ plants.\&text=The $\% 20$ one $\% 2$ Dcelled $\% 20$ plants $\% 20$ use, which $\% 20$ f 
orm\%20new $\% 20$ plant $\% 20$ materia

[16] EarthSky (2015) How Much Do Oceans Add to World's Oxygen? https://oceanservice.noaa.gov/facts/ocean-oxygen.html\#: :text=At\%20least $\% 20$ half \%20of\%20Earth's,Earth\%20comes\%20from\%20the\%20ocean

[17] Li, M., Hu, C., Zhu, Q., Chen, L., Kong, A. and Liu, Z. (2006) Copper and Zinc Induction of Lipid Peroxidation and Effects on Antioxidant Enzyme Activities in the Microalga Pavlova viridis (Prymnesiophyceae). Chemosphere, 62, 565-572. https://doi.org/10.1016/j.chemosphere.2005.06.029

[18] Gonzalez-Pleiter, M., Gonzalo, S., Rodea-Palomares, I., et al. (2013) Toxicity of Five Antibiotics and Their Mixtures towards Photosynthetic Aquatic Organisms: Implications for Environmental Risk Assessment. Water Research, 47, 2050-2064. https://doi.org/10.1016/j.watres.2013.01.020

[19] Magdaleno, A., Saenz, M.E., Juarez, A.B. and Moretton, J. (2015) Effects of Six Antibiotics and Their Binary Mixtures on Growth of Pseudokirchneriella subcapitata. Ecotoxicology and Environmental Safety, 113, 72-78. https://doi.org/10.1016/j.ecoenv.2014.11.021

[20] Villain, J., Minguez, L., Halm-Lemeille, M-P., Durrieu, G. and Bureau, R. (2016) Acute Toxicities of Pharmaceuticals toward Green Algae, Mode of Action, Biopharmaceutical Drug Disposition Classification System and Quantile Regression Models. Ecotoxicology and Environmental Safety, 124, 337-343. https://doi.org/10.1016/j.ecoenv.2015.11.009

[21] Fu, L., Huang, T., Wang, S., Wang, X., Su, L., Li, C. and Zhao, Y. (2017) Toxicity of 13 Different Antibiotics towards Freshwater Green Algae Pseudokirchneriella subcapitata and Their Modes of Action. Chemosphere, 168, 217-222. https://doi.org/10.1016/j.chemosphere.2016.10.043

[22] Aderemi, A.O., Novais, S.C., Alves, L.M., Lemos, M.F.L., Hunter, C. and Pahl, O. (2018) Oxidative Stress Responses and Cellular Energy Allocation Changes in $\mathrm{Mi}$ croalgae following Exposure to Widely Used Human Antibiotics. Aquatic Toxicology, 203, 130-139. https://doi.org/10.1016/j.aquatox.2018.08.008

[23] Lomba, L., Lapena, D., Ros, N., Aso, E., et al. (2020) Ecotoxicological Study of Six Drugs in Aliivibriofischeri, Daphnia magna and Raphidocelis subcapitata. Environmental Science and Pollution Research International, 27, 9891-9900. https://doi.org/10.1007/s11356-019-07592-8

[24] Eguchi, K., Nagase, H., Ozawa, M., Endoh, Y.S., Goto, K., Hirata, K., Miyamoto, K. and Yoshimura, H. (2004) Evaluation of Antimicrobial Agents for Veterinary Use in Ecotoxicity Test Using Microalgae. Chemosphere, 57, 1733-1738. https://doi.org/10.1016/j.chemosphere.2004.07.017

[25] Baran, W., Sochacka, K. and Wardas, W. (2006) Toxicity and Biodegradability of Sulfonamides and Products of Their Photocatalytic Degradation in Aqueous Solutions. Chemosphere, 65, 1295-1299. https://doi.org/10.1016/j.chemosphere.2006.04.040

[26] Geiger, E., Hornek-Gausterer, R. and Sacan, M.T. (2016) Single and Mixture Toxicity of Pharmaceuticals and Chlorophenols to Freshwater Algae Chlorella vulgaris. Ecotoxicology and Environmental Safety, 129, 189-198. https://doi.org/10.1016/j.ecoenv.2016.03.032

[27] Chen, S., Wang, L., Feng, W., Yuan, M., Li, J., Xu, H., Zheng, X. and Zhang, W. (2020) Sulfonamides-Induced Oxidative Stress in Freshwater Microalga Chlorella vulgaris. Evaluation of Growth, Photosynthesis, Antioxidants, Ultrastructure, and 
Nucleic Acids. Scientific Reports, 10, Article No.8243. https://doi.org/10.1038/s41598-020-65219-2

[28] Siedlewicza, G., Zakb, A., Sharmaa, L., Kosakowskaa, A. and Pazdroa, K. (2020) Effects of Oxytetracycline on Growth and Chlorophyll a Fluorescence in Green Algae (Chlorella vulgaris), Diatom (Phaeodactylumtricornutum) and Cyanobacteria (Microcystisaeruginosa and Nodulariaspumigena). Oceanologia, 62, 214-225. https://doi.org/10.1016/j.oceano.2019.12.002

[29] EMEA (2006) Guideline on the Environmental Risk Assessment of Medicinal Products for Human Use. EMEA, London

[30] Ferrat, L., Pergent-Martini, C. and Romeo, M. (2003) Assessment of the Use of Biomarkers in Aquatic Plants for the Evaluation of Environmental Quality: Application to Seagrasses. Aquatic Toxicology, 65, 187-204. https://doi.org/10.1016/S0166-445X(03)00133-4

[31] Juneau, P., Qiu, B. and Deblois, C.P. (2007) Use of Chlorophyll Fluorescence as a Tool for the Determination of Herbicide Toxic Effect: Review. Toxicological and Environmental Chemistry, 89, 609-625. https://doi.org/10.1080/02772240701561569

[32] Pena-Vazquez, E., Perez-Conde, C., Costas, E. and Moreno-Bondi, M. (2010) Development of a Microalgal PAM Test Method for $\mathrm{Cu}(\mathrm{II})$ in Waters: Comparison of Using Spectrofluorometry. Ecotoxicology, 19, 1059-1065. https://doi.org/10.1007/s10646-010-0487-y

[33] Escher, B.I., Bramaz, N., Eggen, R.I.L. and Richter, M. (2005a) In Vitro Assessment of Modes of Toxic Action of Pharmaceuticals in Aquatic Life. Environmental Science and Technology, 39, 3090-3100. https://doi.org/10.1021/es048590e

[34] Escher, B.I., Bramaz, N., Maurer, M., Richter, M., Sutter, D., Von Kanel, C. and Zschokke, M. (2005b) Screening Test Battery for Pharmaceuticals in Urine and Wastewater. Environmental Toxicology and Chemistry, 24, 750-758. https://doi.org/10.1897/04-091R.1

[35] Van der Grinten, E., Pikkemaat, M.G., Brandhof van den, E.J., et al. (2010) Comparing the Sensitivity of Algal, Cyanobacterial, and Bacterial Bioassays to Different Groups of Antibiotics. Chemosphere, 80, 1-6. https://doi.org/10.1016/j.chemosphere.2010.04.011

[36] Bashir, K.M.I. and Cho, M-G. (2016) The Effect of Kanamycin and Tetracycline on Growth and Photosynthetic Activity of Two Chlorophyte Algae. BioMed Research International, 2016, Article ID: 5656304. https://doi.org/10.1155/2016/5656304

[37] Genty, B., Briantais, J-M. and Baker, N.R. (1989) The Relationship between Quantum Yield of Photosynthetic Electron Transport and Quenching of Chlorophyll Fluorescence. Biochimica et Biophysica Acta, 990, 87-92.

https://doi.org/10.1016/S0304-4165(89)80016-9

[38] Maxwell, K. and Johnson, G.N. (2000) Chlorophyll Fluorescence-A Practical Guide. Journal of Experimental Botany, 51, 659-668.

https://doi.org/10.1093/jexbot/51.345.659

[39] Ralph, P.J., Smith, R.A., Macinnis-Ng, C. and Seery, C.R. (2007) Use of Fluorescence-Based Ecotoxicological Bioassays in Monitoring Toxicants and Pollution in Aquatic Systems: Review. Toxicological and Environmental Chemistry, 89, 589-607. https://doi.org/10.1080/02772240701561593

[40] Sjollema, S.B., Redondo-Hasselerharm, P., Leslie, H.A., Kraak, M.H. and Vethaak, A.D. (2016) Do Plastic Particles Affect Microalgal Photosynthesis and Growth? Aquatic Toxicology, 170, 259-261. https://doi.org/10.1016/j.aquatox.2015.12.002 
[41] Cleuvers, M. (2003) Aquatic Ecotoxicity of Pharmaceuticals Including the Assessment of Combination Effects. Toxicological Letter, 142, 185-194. https://doi.org/10.1016/S0378-4274(03)00068-7

[42] Helwig, K., Hunter, C., MacLachlan, J., McNaughtan, M., et al. (2013) Micropollutant Point Sources in the Built Environment: Identification and Monitoring of Priority Pharmaceutical Substances in Hospital Effluents. Journal of Environmental and Analytical Toxicology, 3, 177.

[43] Hughes, S.R., Kay, P. and Brown, L.E. (2013) Global Synthesis and Critical Evaluation of Pharmaceutical Data Sets Collected from River Systems. Environmental Science and Technology, 47, 661-677. https://doi.org/10.1021/es3030148

[44] Kaplan, S. (2013) Review: Pharmacological Pollution in Water. Critical Review, Environmental Science and Technology, 43, 1074-1116.

https://doi.org/10.1080/10934529.2011.627036

[45] Ortiz de Garcia, S., Pinto, G.P., Garcia-Encina, P.A. and Irusta Mata, R.I. (2013) Ranking of Concern, Based on Environmental Indexes, for Pharmaceutical and Personal Care Products: An Application to the Spanish Case. Journal of Environmental Management, 129, 384-397. https://doi.org/10.1016/j.jenvman.2013.06.035

[46] Johnson, A.C., Keller, V., Dumont, E. and Sumpter, J.P. (2015) Assessing the Concentrations and Risks of Toxicity from Antibiotics Ciprofloxacin, Sulfamethoxazole, Trimethoprim, and Erythromycin in European Rivers. Science of the Total Environment, 511, 747-755. https://doi.org/10.1016/j.scitotenv.2014.12.055

[47] Machado, M.D. and Soares, E.V. (2019) Sensitivity of Freshwater and Marine Green Algae to Three Compounds of Emerging Concern. Journal of Applied Phycology, 31, 399-408. https://doi.org/10.1007/s10811-018-1511-5

[48] USEPA, United States Environmental Protection Agency (2002) Short-Term Methods for Estimating the Chronic Toxicity of Effluents and Receiving Waters to Freshwater Organisms (EPA-821-R-02-013). 4th Edition, USEPA, Washington DC.

[49] OECD (2006) Test No. 201: Freshwater Alga and Cyanobacteria, Growth Inhibition Test. OECD Guidelines for the Testing of Chemicals, Paris.

[50] Van Gestel, C.A., Van der Waarde, J.J., Derksen, J.G.M., et al. (2001) The Use of Acute and Chronic Bioassays to Determine the Ecological Risk and Bioremediation Efficiency of Oil Polluted Soils. Environmental Toxicology and Chemistry, 20, 1438-1449. https://doi.org/10.1002/etc.5620200705

[51] Zounkova, R., Kovalova, L., Blaha, L. and Dott, W. (2010) Ecotoxicity and Genotoxicity Assessment of Cytotoxic Antineoplastic Drugs and Their Metabolites. Chemosphere, 81, 253-260. https://doi.org/10.1016/j.chemosphere.2010.06.029

[52] Radix, P., Leonard, M., Papantoniou, C., Roman, G., et al. (2000) Comparison of Four Chronic Toxicity Tests Using Algae, Bacteria, and Invertebrates Assessed with Sixteen Chemicals. Ecotoxicology and Environmental Safety, 47, 186-194. https://doi.org/10.1006/eesa.2000.1966

[53] Isidori, M., Lavorgna, M., Nardelli, A., Pascarella, L. and Parrella, A., (2005) Toxic and Genotoxic Evaluation of Six Antibiotics on Non-Target Organisms. Science of the Total Environment, 346, 87-98. https://doi.org/10.1016/j.scitotenv.2004.11.017

[54] European Commission (2003) Technical Guidance on Risk Assessment in Support of Commission Directive 93/67/EEC on Risk Assessment for New Notified Substances Commission Regulation (EC) No 1488/94, on Risk Assessment for Existing Substances Directive 98/8/RC of European Parliament and of the Council Concerning the Placing of Biocidal Products on the Market. EUR 20418 EN/2. Office for Official Publications of the European Communities, Luxembourg, 1-337. 
[55] Pack, S. (1993) A Review of Statistical Data Analysis and Experimental Design in OECD Aquatic Toxicology Test Guidelines. Organisation of Economic Cooperation and Development, Paris, $42 \mathrm{p}$.

[56] Suter, G.W. (1996) Abuse of Hypothesis Testing Statistics in Ecological Risk Assessment. Human and Ecological Risk Assessment, 2, 331-347. https://doi.org/10.1080/10807039609383611

[57] Kasai, F. and Hatakeyama, S. (1993) Herbicide Susceptibility in Two Green Algae, Chlorella vulgaris and Selenastrum capricornutum. Chemosphere, 27, 899-904. https://doi.org/10.1016/0045-6535(93)90019-2

[58] Kasai, F., Takamura, N. and Hatakeyama, S. (1993) Effects of Simetryne on Growth of Various Freshwater algal Taxa. Environmental Pollution, 79, 77-83. https://doi.org/10.1016/0269-7491(93)90180-V

[59] Cedergreen, N., Streibig, J.C., Kudsk, P., et al. (2007) The Occurrence of Hormesis in Plants and Algae. Dose-Response, 5, 150-162. https://doi.org/10.2203/dose-response.06-008.Cedergreen

[60] Calabrese, E.J. (2009) Getting the Dose-Response Wrong: Why Hormesis Became Marginalized and the Threshold Model Accepted. Archives of Toxicology, 83, 227-247. https://doi.org/10.1007/s00204-009-0411-5

[61] Nie, X.P., Liu, B.Y., Yu, H.J., Liu, W.Q. and Yang, Y.F. (2013) Toxic Effects of Erythromycin, Ciprofloxacin, and Sulfamethoxazole Exposure to the Antioxidant System in Pseudokirchneriella subcapitata. Environmental Pollution, 172, 23-32. https://doi.org/10.1016/j.envpol.2012.08.013

[62] Liu, B., Liu, W., Nie, X., Guan, C., Yang, Y., Wang, Z. and Liao, W. (2011) Growth Response and Toxic Effects of Three Antibiotics on Selenastrum capricornutum Evaluated by Photosynthetic Rate and Chlorophyll Biosynthesis. Journal of Environmental Sciences, 23, 1558-1563. https://doi.org/10.1016/S1001-0742(10)60608-0

[63] Borecka, M., Bialk-Bielinska, A., Halinski, L.P., Pazdro, K., Stepnowski, P. and Stolte, S. (2016) The Influence of Salinity on the Toxicity of Selected Sulfonamides and Trimethoprim towards the Green Algae Chlorella vulgaris. Journal of Hazardous Materials, 308, 179-186. https://doi.org/10.1016/j.jhazmat.2016.01.041

[64] Black, C.C., San Pietro, A., Limbach, D. and Norris, G. (1963) Photosynthetic Phosphorylation Catalysed by Factors Isolated from Photosynthetic Organisms. Proceedings of the National Academy of Science (U.S), 50, 37-43. https://doi.org/10.1073/pnas.50.1.37

[65] Maclean, F.I., Fujita, Y., Forrest, H.S. and Myers, J. (1965) Photosynthetic Phosphorylation: Stimulation by Pteridines and a Comparison with Phosphodoxin. Science, 149, 636-638. https://doi.org/10.1126/science.149.3684.636

[66] Fuller, R.C. and Nugent, N.A. (1969) Pteridines and the Function of the Photosynthetic Reaction Centre. Proceedings of the National Academy of Science (U.S), 63, 1311-1318. https://doi.org/10.1073/pnas.63.4.1311

[67] European Commission (2001) General Classification and Labelling Requirements for Dangerous Substances and Preparations.

http://ec.europa.eu/environment/archives/dansub/pdfs/annex6 en.pdf

[68] McFadden, G.I. and Roos, D.S. (1999) Apicomplexan Plastids as Drug Targets. Trends in Microbiology, 7, 328-333. https://doi.org/10.1016/S0966-842X(99)01547-4

[69] Roberts, J., et al. (2015) noPILLS River Monitoring Data. Personal Communication, Glasgow. 
[70] European Commission (2015) Commission Implementing Decision (EU) 2015/495 of 20 March 2015 Establishing a Watch List of Substances for Union-Wide Monitoring in the Field of Water Policy Pursuant to Directive 2008/105/EC of the European Parliament and of the Council. Official Journal of the European Union, 78, 40-42. 